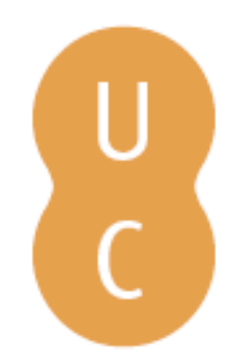

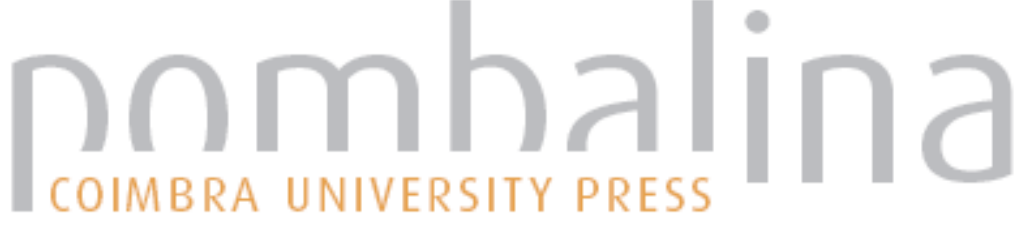

Age at menarche in athletes: interactions among central mechanisms

Autor(es): Rogol, Alan D

Publicado por: Imprensa da Universidade de Coimbra

URL

persistente: URI:http://hdl.handle.net/10316.2/38555

DOI: $\quad$ DOI:http://dx.doi.org/10.14195/978-989-26-0773-3_13

Accessed : $\quad$ 26-Apr-2023 16:34:39

A navegação consulta e descarregamento dos títulos inseridos nas Bibliotecas Digitais UC Digitalis, UC Pombalina e UC Impactum, pressupõem a aceitação plena e sem reservas dos Termos e Condições de Uso destas Bibliotecas Digitais, disponíveis em https://digitalis.uc.pt/pt-pt/termos.

Conforme exposto nos referidos Termos e Condições de Uso, o descarregamento de títulos de acesso restrito requer uma licença válida de autorização devendo o utilizador aceder ao(s) documento(s) a partir de um endereço de IP da instituição detentora da supramencionada licença.

Ao utilizador é apenas permitido o descarregamento para uso pessoal, pelo que o emprego do(s) título(s) descarregado(s) para outro fim, designadamente comercial, carece de autorização do respetivo autor ou editor da obra.

Na medida em que todas as obras da UC Digitalis se encontram protegidas pelo Código do Direito de Autor e Direitos Conexos e demais legislação aplicável, toda a cópia, parcial ou total, deste documento, nos casos em que é legalmente admitida, deverá conter ou fazer-se acompanhar por este aviso. 


\section{GROWTH AND \\ MATURATION \\ IN HUMAN BIOLOGY \\ AND SPORTS}

FESTSCHRIFT HONORING ROBERT M. MALINA

BY FELLOWS AND COLLEAGUES

PETER TODD KATZMARZYK MANUEL J COELHO E SILVA

EDITORS 


\title{
AGE AT MENARCHE IN ATHLETES: INTERACTIONS AMONG CENTRAL MECHANISMS
}

\author{
Alan D Rogol
}

\section{INTRODUCTION}

It is indeed and honor and privilege to dedicate this chapter to Robert. M. Malina, Ph.D. I have chosen a subject upon which Bob has written extensively; that of menarche in athletes. Rather than take the "usual" approach and just catalog the age at menarche in various sports and the sub-disciplines within them (many, including himself, have done that extensively), he has taken the scientific/sociologic approach noting that these are young women first, and then athletes. He has extensively studied the effects of sibship, birth order, socio-economic class, etc, as covariates for the training time (volume), and intensity of that training [as reviewed in (Malina, et al, 2004)].

I shall not merely point out the multiple studies that Bob has done or reviewed, but shall emphasize the great variability of age at menarche among all adolescents before moving to an experimental basis likely accounting for secondary amenorrhea among adolescent athletes. The latter because it likely informs us about menarche as well, although this pivotal event in an adolescent girl's life has not been as extensively studied. I shall end with some more speculative findings in the discipline of hypogonadotropic hypogonadism, for the data presented point to variability in genes than affect both gonadotropin-releasing hormone $(\mathrm{GnRH})$ physiology and the hypothalamic regulation of appetite. An intriguing hypothesis is that any variety of stress, in this case high energy exercise in the presence of diminished eating, and perhaps activation of the hypothalamicpituitary-adrenal axis, may have an intensified effect on the reproductive axis (luteal phase defect and secondary amenorrhea, and by analogy, primary amenorrhea) in those women with heterozygous alterations in one of the several affected genes (Mitchell, et al, 20l I; Caronia, et al, 201 I).

Data for the age at menarche are simply descriptive (Mclntyre and Kacerosky, 201 I). They do account for variability within the specific group studied without attribution for the breadth of that variability. It should be noted that menarche is a very late event within pubertal maturation, lagging by several years the re-initiation of pulsatile GnRH (and thus luteinizing hormone, $\mathrm{LH}$ ) secretion, the phases of follicular development, the growth spurt and external indicators of adolescent maturation-breasts and the addition and redistribution of body fat. Although puberty progresses in an orderly fashion, there is much variability in its onset, progression and completion (beyond menarche). However, once entrained the variability between stages (tempo), although still present, is less. Most girls 
will experience menarche between 2 and 2.5 years after breast budding, although some of those having breast budding early will have a more desultory progression to menarche (Styne \& Grumbach, 2004). They may show breast budding 2 or 3 years earlier than average, but menarche only a few months before the median age of menarche for that ethnic/racial group (Rosenfield, 2009)

Utilizing data from the mid-1970's to the mid-1990's, as summarized by Malina, et al (2004) the median age at menarche for North American girls was approximately 12.4 years with a breakdown of 12.1 years for Blacks, 12.5 years for Mexican-Americans, and 12.6 years for Whites. These are reference data from extensive cohorts obtained from multiple National Health and Nutrition Examination Surveys (NHANES) studies and individual studies such as the Bogalusa Heart Study (Anderson, et al, 2003; Freedman, et al, 2002; Wattigney et al, 1999). Within Europe there is an extensive north-south gradient with median ages at menarche varying from 12.7 to 13 years in Sweden to 12.4 to 12.7 years in Italy [summarized in Malina, et al (2004)].

Over the past 150 years there has been a secular trend for the lowering of age at menarche moving from approximately 17 years to a relative plateau over the past 50 years, at least in the more developed portions of the world, of about 12.5 years (Wyshak \& Frisch, 1982, Wattigney, et al, 1999). There are likely multiple and intertwining reasons for this decline and they include better nutrition and clean water, eradication of many infectious diseases, and improvements in overall health status. The psychological impact of earlier maturation has not been well studied, but there is seemingly a greater disparity between physical maturation and social/emotional development, recently (Hillard, 2008). In addition there is the potential for adverse health consequences on conditions such as breast cancer.

\section{AGE AT MENARCHE IN ATHLETES}

Professor Malina has extensively studied and written about this subject from the methodologic (prospective or longitudinal; status quo; and the retrospective) point of view. The first two are to be desired, but often do not account for the "elite" status in many younger girls or those who drop out during the trajectory toward elite status - thus having bias toward those adolescents who continue to train at high levels of energy expenditure. The retrospective sets of data are most prominent, for these studies are the "easiest" to perform, but have the potential for error of recall, likely greater the longer the time interval between the event (menarche) and when the adolescent is asked for the date of menarche. It may prove useful in such studies to corroborate the date with the athlete's mother.

A snapshot summary has been presented by Malina et al (2004) showing the median and $95 \%$ confidence intervals for non-athletes in the studies reviewed (13.0 \pm I.0 years) with $95 \% \mathrm{Cl}$ ( I I.0 to 15.0 years). Athletes in various sports are compared against that background with the greatest delays in gymnasts and ballet dancers and perhaps, slight 
acceleration in rowers and track and field athletes. These are of course global reference estimates without breaking down individual disciplines within, for example, track and field. As expected the aesthetic sports where high volumes of exercise are paired with diminished nutrient intake to satisfy the linear physic expected, for example ballet and diving, show on average, the greatest delay in menarcheal age. As noted by Malina, et al (2004) the sample sizes of adolescent athletes are generally small.

Longitudinal studies have even smaller numbers of girls and are potentially confounded by selective exclusion or drop out begging the question of selection for later maturing girls (more below re: gymnasts) or whether earlier maturing adolescents selectively drop out of gymnastics, ballet and other aesthetic sports. For example, artistic gymnastics is so selective that the elite athletes may approximate $0.1 \%$ of those that partake in the sport [Malina, et al., $20 \mathrm{ll}$ ]. Adolescents who compete at the International level are very significantly smaller and lighter than those of non-elite status and even more so compared to a non-athletic cohort. However, one must consider many more attributes of these elite adolescent athletes - their parents are shorter than average and the girls themselves are shorter than average for their age even before they began to train (Malina, et $a \mathrm{l}, 20 \mathrm{II}$ ). The growth and maturity characteristics differ among those who persist in the sport and those who drop out. Summarizing four small cohorts of female artistic gymnasts from Poland, Switzerland, Belgium, and Canada (Malina, et al, 20 II; Claessens, et al, 1999; Roupas \& Georgopoulos, 20II) found that girls who persisted in their training and competition were shorter on average at 12-15 years than those who dropped out. In contrast those who persisted were lighter throughout the age range. Those who persisted with training, reached peak height velocity late and attained menarche only slightly later; however, the sample sizes were very small. 

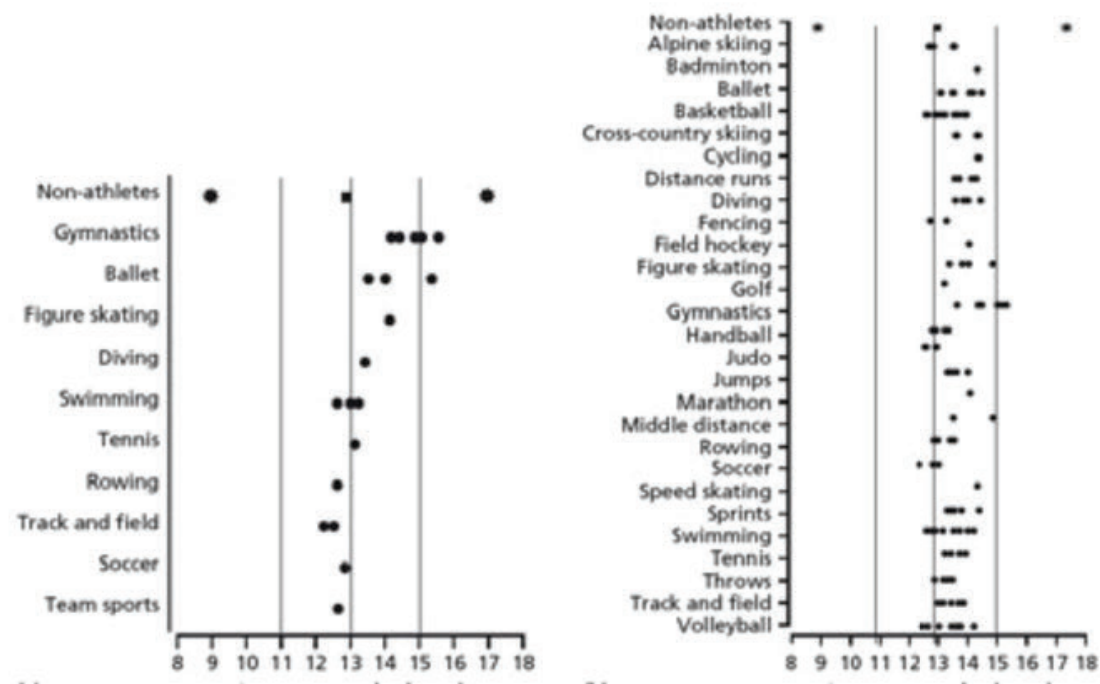

Figure I. Mean ages at menarche in adolescent athletes grouped by sport: longitudinal and status quo studies (left), retrospective studies (right).

\section{HYPOTHALAMIC-PITUITARY-GONADAL (HPG) AXIS}

The hypothalamic-pituitary-gonadal axis is active during the latter two-thirds of fetal life in both sexes. At birth the abrupt disconnection of the placenta markedly diminishes the levels of placental-derived estrogens with immediate consequences of these lower levels on the hypothalamus and pituitary. During neonatal/infancy maturation in boys there is a well-described pattern of gonadotropin [predominantly luteinizing hormone $(L H)$ ] and testosterone levels. The previously suppressed gonadotropins $[\mathrm{LH}$ and follicle-stimulating hormone (FSH)] are suddenly released from negative feedback as estradiol levels decrease from birth. During the first few weeks of life LH and FSH levels increase followed by an increase in testosterone over approximately the first 12 weeks of life. This "mini-puberty" wanes to be followed by the juvenile "hiatus", which itself ends with the onset of pubertal maturation (Fuqua \& Rogol, 20l I).

The mean level of FSH is clearly higher in the female and remains elevated over the childhood baseline for approximately 2 years. The consequences of this are raised levels of estradiol. It is at these times (6-24 months) that girls may have thelarche (appearance of glandular breast tissue), which regresses after the second year and remains 
"suppressed" until the re-awakening of the HPG axis as pubertal maturation unfolds (Fuqua \& Rogol, 20। I).

The first external sign of physiological puberty is most often thelarche. For this to occur there had to have been a re-awakening of the HPG axis where the very low concentrations of estradiol are no longer capable to restrain the pulsatile release of $\mathrm{GnRH}$. The pituitary is sensitive to the frequency and amplitude of these $\mathrm{GnRH}$ pulses and responds with pulsatile $\mathrm{LH}$ and $\mathrm{FSH}$ release, the composition of the mixture depending on the frequency of the GnRH pattern (Fuqua \& Rogol, 20l I).

It is intriguing to note an inverse relationship between low birth weight and age of pubertal onset as well as menarche. In those with low birth weight, but subsequently become obese (BMI $>95^{\text {th }}$ centile) menarche is advanced by approximately 6 months (McCartney, et al, 2009).

Luteinizing hormone induces the follicle to produce precursors to estradiol whereas FSH induces the enzyme aromatase to synthesize these precursors (androgens) into estrogens. Menarche occurs at least a year beyond continuously increasing estradiol levels and likely an alteration in negative feedback on the hypothalamus permitting a small window of positive feedback [increasing levels of estradiol lead to increases in $\mathrm{LH}$ secretion (ovulatory spike)], ovulation, and the formation of the corpus luteum. Obesity has an effect on the reproductive axis by perhaps having an earlier start of puberty, but often a not so early menarche given the higher levels of testosterone and lower levels of sex hormone-binding globulin, yielding higher levels of free (biologically active) testosterone (McCartney, et al, 2009). Just the opposite occurs with the thin athletes with a later start of activation of the HPG axis and the nutritionally-activated signals. This leads directly to an interaction of the signals of the HPG axis and those of appetite (satiety) as noted below.

\section{APPETITE-SATIETY}

Regulation of body weight is a precise, clearly complex, process that keeps caloric intake balanced to expenditure within an error range of approximately $1.25 \%$ (Yanovsky, et al, 2000). There are a series of inputs into the central nervous system, likely integrated in multiple nuclei of the hypothalamus. These signals are hormonal, metabolic and neuronal and detect and alter the delicate balance of total energy to permit normal physiologic function (including reproduction) and body weight over years and decades. For women the issue of reproductive competence is closely allied with the total energy balance. A woman can survive famine more easily, if she is not reproductively competent. If the reproductive system can be dampened only to reawaken at times of positive overall energy balance, this is salutary for preservation of the species - fecundity during times of nutritional adequacy and infertility during times of critical caloric availability (van der Walt, et al, 1978). 
This is clearly the case for the hunter-gatherers of the northwestern Kalahari Desert (van der Walt, et al, 1978). It is only recently that some of the neuroendocrine mechanisms have been unraveled. Functional hypothalamic amenorrhea (FHA) and its subset in athletes are characterized by hypoestrogenemia, in the presence of low or normal concentrations of gonadotropins without any known (medical) cause. Athletes with FHA are of low body weight, obtain sub-balance amounts of nutrients and exercise extensively (Chou, et al, $20 \mathrm{ll}$ ). As expected for their low subcutaneous fat mass, the leptin levels are low. Although the balance of orexigenic (for example, NPY acting through PYY receptors and anorexigenic hormones (for example, pro-opiomelanocortin, POMC) should be tilted toward food intake, these women do not increase their caloric intake to balance the energy output (Russell, et al, 20 I I).

\section{LEPTIN DEFICIENCY}

Children with congenital leptin or leptin receptor deficiency are stark examples of the importance of leptin action for energy balance. Girls with either gene deficiency (LEP or $L E P R)$ are markedly obese even within the first year of life and have delayed puberty in the second decade. Leptin treatment of girls with LEP deficiency markedly alters the appetite, permits significant weight loss and entry ("permissive") and progression through puberty (Farooqi, et al, 1999, 2007). More recent data noting central action on appetite centers are summarized by Farooqi $(2010)$.

Leptin activates the POMC neurons and inhibits Agouti-related peptide (AgRP)/NPY neurons within the arcuate nucleus of the hypothalamus to stimulate feeding - in fact this has been shown in female runners with HA-infusions of leptin (Welt, et al, 2004) or chronic administration of metreleptin (a longer-acting analog of leptin) have reversed HA in some of the athletes (Chou, et al, 20l I). Loucks and colleagues have noted that the HPG axis of adolescents (younger gynecological age) is more susceptible to net energy decrements than in the gynecologically older woman (Loucks, et al, 2006).

\section{OVARIAN CYCLES AND HYPOTHALAMIC AMENORRHEA}

Thus, it does not seem such a leap of logic to suspect that the very early ovarian cycles of the pre-menarcheal adolescent may be quite sensitive to the combination of high energy expenditure, sub-sufficient caloric intake, and stress which might delay (or prolong) adolescent maturation, including menarche. Additionally, many elite artistic gymnasts, for example, conform to the growth and maturational characteristics of short, delayed girls [and their families (Malina, et al, 20 I I)]. It is not so surprising that these adolescent athletes may have the greatest delay in their maturational trajectory. 
An additional factor may involve mutations in genes that control energy balance and the HPG axis. One might consider the genes which in their homozygous form cause idiopathic hypogonadotropic hypogonadism $(\mathrm{HH}$ ) - that is, permanent $\mathrm{HH}$ (Mitchell, et al, 20 I I) may in their heterozygous form delay menarche or increase the susceptibility to environmental factors that might lead to FHA (Carmina, et al, $20 \mathrm{ll}$ ). In a group of women with HA ( $\mathrm{N}=55)$ including some who exercised more than $5 \mathrm{hr} /$ week, weight loss and subclinical eating disorders, 7/55 (13\%) were noted to have heterozygous mutations in a number of genes, fibroblast growth factor I receptor (FGFRI), prokineticin receptor 2 (PROKR2), Kallmann syndrome I sequence (KAL I) GnRH receptor I (GNRHR). No mutations were found in 422 control women with normal menstrual cycles (Carmina, et al, $20 \mathrm{II}$ ). These genes play fundamental roles in GnRH ontogeny and physiology including alterations in the pulsatile release of GnRH. Several of these, for example, FGFR I (Sun, et al, 2007) and PROKR 2 (Gardiner, et al, 20 I0) signaling also affect eating behavior, at least in mice.

An intriguing hypothesis that may account for many of these findings is that the delayed menarche in some of the adolescent athletes is due to a combination of genetic factors leading to a small, delayed maturational phenotype and low caloric intake, and the stress of training and competition perhaps modified by heterozygous alterations in a small subset of genes that affect hypothalamic function for $\mathrm{GnRH}$ physiology and energy balance. Whatever the predominant reasons for delayed menarche in adolescent athletes, it is clear that it is not a single cause and likely a series of causes, individual to each adolescent.

SUMMARY

What has Bob Malina taught me about the subject of age at menarche in athletes? It is to use the scientific method to tease out other (perhaps confounding) factors within the girl/adolescent athlete that might affect the simple relationship of athletic training/competition, however quantitated. His insight into the sociological and psycho/social aspects of the young woman's life is merely his way of making a very simple statement: the athlete is a girl/adolescent first with the sum total of her genetics and daily/family life upon which her athletic training/competition is superimposed.

\section{REFERENCES}

Anderson, S.E., Dallal G.E. and Must, A., 2003, Relative weight and race influence average age at menarche: results from two nationally representative surveys of US girls studied 25 years apart.. Pediatrics, I I I, pp. 844-850.

Caronia, L.M., Martin, C., Welt, C., Sykiotis, G.P., Quinton, R., Thambundit, A., Avbelj, M., Dhruvakumar, S, Plummer, L., Hughes, V.A., Seminara, S.B., Boepple, P.A., Sidis, Y., Crowley, Jr, W.F., Martin, K.A., Hall, J.E. and Pitteloud, N., 20I I, A genetic basis for functional hypothalamic amenorrhea. New England Journal of Medicine. 364, pp. 215-225. 
Chou, S.H., Chamberland, J.P., Liu, X., Matarese, G., Gao, C., Stefanakis, R., Brinkoetter, M.T., Gong, H., Arampatzi, K. and Mantzoros, C.S., 20lI, Leptin is an effective treatment for hypothalamic amenorrhea. Proceedings of the National Academy of Science, in press, 2011

Claessens, A.L., Lefevre, J., Beunen, G. and Malina, R.M., 1999, The contribution of anthropometric characteristics to performance scores in elite female gymnasts. Journal of Sports Medicine and Physical Fitness, 39, pp. 355-360.

Farooqi, I.S., 2010, Genetic, molecular and physiological insights into human obesity. European Journal of Clinical Investigation, 4I , pp. 45 I-455.

Farooqi, I.S., Jebb, S.A., Langmack, G., Lawrence, E., Cheetham, C.H., Prentice, A.M., et al, 1999, Effects of recombinant leptin therapy in a child with congenital leptin deficiency. New England Journal of Medicine, 34 I, pp. 879-884.

Farooqui, I.S., Wangensteen, T., Collins, S., Kimber, W., Matarese, G., Keogh, J.M., et al, 2007, Clinical and molecular genetic spectrum of congenital deficiency of the leptin receptor. New England Journal of Medicine, 356, pp. 237-247.

Freedman, D.S., Khan, L.K., Serdula, M.K., Dietz, W.H., Srinivasan, S.R. and Berenson, G.S., 2002, Relation of age at menarche to race, time period, and anthropometric dimensions: the Bogalusa Hear Study. Pediatrics, I I 0, pp. e43.

Fuqua, J.S. and Rogol, A.D., 20II, Delayed puberty and hypogonadism. In Oxford Textbook of Endocrinology and Diabetes, $2^{\text {nd }}$ ed, edited by Wass, J.A.H., Stewart, P.M., Amiel, S.A. and Davies, M.J., (Oxford: Oxford Press), pp. a-b.

Gardiner, J.V., Bataveljic, A., Patel, N.A., Bewick, G.A., Roy, D., Campbell, D., Greenwood, H.C., Murphy, K.G., Hameed, S., Jethwa, P.H., Ebling, F.J.P., Vickers,.S.P., Cheetham, S., Ghatei, M.A.., Bloom, S.R. and Dhillo, W.S., 20l0, Prokineticin 2 is a hypothalamic neuropeptide that potently inhibits food intake. Diabetes 59, pp. 397406.

Hillard, P.J., 2008, Menstruation in adolescents: What's normal and what's not. Annals of the New York Academy of Science, I I 35, pp. 29-35.

Loucks, A.B., 2006, The response of luteinizing hormone pulsatility to 5 days of low energy availability disappears by 14 years of gynecological age. Journal of Clinical Endocrinology and Metabolism, 91, pp. 3158-3164.

Malina, R.M., Bouchard, C. and Bar-Or, O., 2004, Growth, Maturation, and Physical Activity, (Champaign, IL, Human Kinetics).

Malina, RM., et al, 20II, FIG report [I shall complete the reference when the report is finalized]

McCartney, C.R., Prendergast, K.A., Blank, S.K., Helm, K.D., Chhabra, S. and Marshall, J.C., 2009, Maturation of luteinizing hormone (gonadotropin-releasing hormone) secretion across puberty: Evidence for altered regulation in obese peripubertal girls. Journal of Clinical endocrinology and Metabolism. 94, pp. 56-66.

Mclntyre, M.M. and Kacerosky, P.M., 201 I, Age and size at menarche. American Journal of Human Biology. 23:305-312.

Mitchell, A.L., Dwyer, A., Pitteloud, N. and Quinton, R., 201।, Genetic basis and variable phenotype expression of Kallmann syndrome: towards a unifying theory. Trends in Endocrinology and Metabolism. 
Rosenfield, R.L., Lipton, R.B. and Drum, M.L., 2009, Thelarche, pubarche, and menarche attainment in children with normal and elevated body mass index. Pediatrics, 123, pp. 84-88.

Roupas, N.D. and Georgopoulos, N.A., 201 I, Menstrual function in sports. Hormones, I0, pp. $104-1 \mid 6$.

Russell, M., Stark J., Nayak, S., Miller, K.K., Herzog, D.B., Klibanski, A., Misra, M., 2009, Peptide $Y Y$ in adolescent athletes with amenorrhea, eumenorrheic athletes and non-athletic controls. Bone, 45, pp. 104-109.

Styne, D.M.and Grumbach, M.M., 2008, Puberty: Ontogeny, neuroendocrinology, physiology and disorders. In Williams Textbook of Endocrinology, I I ${ }^{\text {th }}$ ed., edited by Kronenberg HM.., Melmed S., Polonsky KS., and Larsen PR., (Philadelphia: Saunders), pp. 969-। I66.

Sun, H.D., Malabunga, M., Tonra, J.R., DiRenzo, R., Carrick, H.D., Zheng, H., Berthoud, H.R., McGuinness, O.P., Shen, J., Bohlen, P., Leibel, R.L. and Kussie, P., 2007, Monoclonal antibody antagonists of hypothalamic FGFRI cause potent but reversible hypophagia and weight loss in rodents and monkeys. American Journal of Physiology (Endocrinology and Metabolism), 292, pp. E964-E976.

Van der Walt, L.A., Wilmsen, E.N. and Jenkins, T., 1978, Unusual sex hormone patterns among desert-dwelling hunter-gatherers. Journal of Clinical Endocrinology and Metabolism, 46, pp. 658-663.

Wattigney, W.A., Srinivasan, S.R., Chen, W., Greenlund, K.J. and Berenson, G.S., 1999, Secular trend of earlier onset of menarche with increasing obesity in black and white girls: the Bogalusa Heart Study. Ethnicity Diseases, 9 pp. |8|- |89.

Welt, C.K., Chen, J.L., Bullen, J., Murphy, R., Smith, P., DePaoli, A.M., Karalis, A. and Mantzoros, C.S., 2004, Recombinant human leptin in women with hypothalamic amenorrhea. New England Journal of Medicine, 35 I, pp. 987-997.

Wyshak G. and Frisch R.E., 1982, Evidence for a secular trend in age of menarche. New England Journal of Medicine, 306, pp. 1033-1035.

Yanovsky, J.A., Yanovski, S.Z., Sovik., K.N., Nguyen, T.T., O'Neil, P.M. and Sebring, N.G., 2000, A prospective study of holiday weight gain. New England Journal of Medicine, 342, pp. 86I-867. 